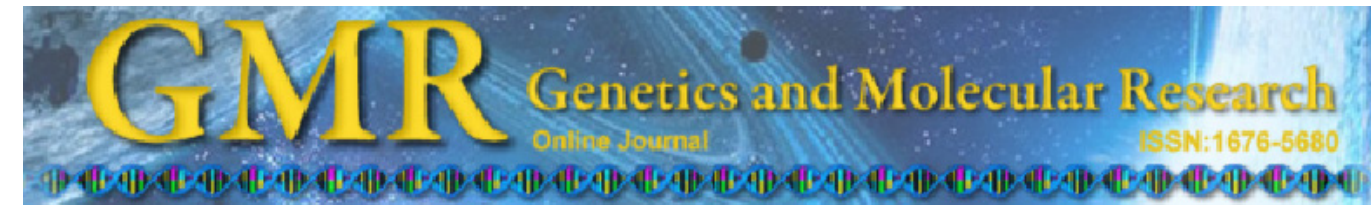

\title{
High degree of genetic diversity among genotypes of the forage grass Brachiaria ruziziensis (Poaceae) detected with ISSR markers
}

\author{
A.L.S. Azevedo, P.P. Costa, M.A. Machado, C.M.P. de Paula and F.S. Sobrinho \\ Embrapa Gado de Leite, Juiz de Fora, MG, Brasil \\ Corresponding author: A.L.S. Azevedo \\ E-mail: azevedo@cnpgl.embrapa.br
}

Genet. Mol. Res. 10 (4): 3530-3538 (2011)

Received March 2, 2011

Accepted July 12, 2011

Published November 17, 2011

DOI http://dx.doi.org/10.4238/2011.November.17.5

\begin{abstract}
The grasses of the genus Brachiaria account for $80 \%$ of the cultivated pastures in Brazil. Despite its importance for livestock production, little information is available for breeding purposes. Embrapa has a population of B. ruziziensis from different regions of Brazil, representing most of existing variability. This population was used to initiate an improvement program based on recurrent selection. In order to assist the genetic improvement program, we estimated the molecular variability among 93 genotypes of Embrapa's collection using ISSR (inter-simple sequence repeat) markers. DNA was extracted from the leaves. Twelve ISSR primers generated 89 polymorphic bands in the 93 genotypes. The number of bands identified by each primer ranged from two to 13 , with a mean of 7.41. Cluster analysis revealed a clearly distinct group, containing most of the B. ruziziensis genotypes apart from the outgroup genotypes. Genetic similarity coefficients ranged from 0.0 to 0.95 , with a mean of 0.50 and analysis of molecular variance indicated higher variation within $(73.43 \%)$ than among species $(26.57 \%)$. We conclude that there is a high genetic diversity among these $B$. ruziziensis genotypes, which could be explored by breeding programs.
\end{abstract}

Key words: Genetic variability; Forage; Molecular markers 


\section{INTRODUCTION}

Pastures are very important for agriculture in Brazil since they account for $75 \%$ of the agricultural lands in the country. The main feeding source of the enormous cattle herd in Brazil (200 million head) is through forage. Pastures, as sole food source, are responsible for almost $90 \%$ of beef and the majority of 25.7 billion liters of milk produced annually in the country (Souza Sobrinho et al., 2009). Starting in 1960, mainly during the 1970s and 1980s, areas of natural grassland have been replaced by cultivated pastures, mainly with species of the genus Brachiaria (Martha Júnior and Corsi, 2001). Of a total of 180 million hectares covered by pastures in the country, it is estimated that cultivated pastures account for 105 million hectares and $80 \%$ of these are cultivated with Brachiaria grasses (Pereira, 1998; Dusi, 2001).

In Brazil, the most cultivated species of Brachiaria are B. decumbens, $B$. brizantha, $B$. humidicola and B. ruziziensis. Among these species, B. ruziziensis is the only sexual and diploid species, allowing the crossing of genotypes and generation of variability for selection. Although B. ruziziensis is not a species with a large cultivated area, the demand for seeds is increasing following the advancement of integration between agriculture and livestock production.

Integration between agriculture and livestock production is an important alternative to pasture recuperation and improvement of annual crops. It increases straw to minimum tillage systems, improves soil chemical, physical and biological properties, allows better use of equipment, and improves farmers' income and jobs in rural areas (Macedo, 2009). B. ruziziensis has been commonly used in agriculture livestock integrated systems mainly due to its better adaptation to overseeding, less herbicide demand for drying and establishment of the next crop, and also its small tussock architecture.

Despite the importance of Brachiaria for livestock production, the available information about the biology and genetics of this genus is very limited, especially for breeding purposes. Introduction of genetic variability in cultivated species was somehow accomplished with few crossings and introduction of different accessions. Natural recombination may have also occurred during the past 50 years that Brachiaria was introduced in Brazil. Characterization of genetic diversity in a population is required for better exploitation of genetic resources in breeding programs, and is a critical factor that contributes to preserve biodiversity. Knowledge of genetic diversity is essential in the development of commercial hybrids. Diversity can be assessed using many tools including DNA markers (Kapila et al., 2008).

Molecular markers are valuable tools in the characterization and evaluation of genetic diversity within and between species and populations. Knowing the degree of genetic similarity among different genotypes is useful to organize a working collection, to identify heterotic groups, and to select genotypes for crosses (Bonato et al., 2006). It has been shown that different markers may reveal different classes of variation (Powell et al., 1996; Russell et al., 1997). This could be explained by the genome fraction surveyed by each type of marker, their distribution throughout the genome and the extent of the DNA target which is analyzed by each specific assay (Dávila et al., 1999). Molecular markers such as random amplified polymorphic DNA (RAPD), inter-simple sequence repeats (ISSR), simple sequence repeats (SSR) and amplified fragment length polymorphism (AFLP) have been successfully used to assess the genetic diversity in cultivars of many plant species (Balasaravanan et al., 2003; Khan et al., 2005; Martos et al., 2005; Terzopoulos et al., 2005). ISSR markers show some advantages since these markers overcome the shortcomings of the low reproducibility of RAPD, the high cost of AFLP and the complex generation of SSR 
(Reddy et al., 2002), and represents a fast and cost-efficient technique.

Selection and assessment of genotypes with ISSR markers could aid breeding processes by separating closely related genotypes, thus increasing the efficiency and orientation of future crossings and genetic studies. The Brazilian Agricultural Research Corporation (Embrapa) coordinates the genetic improvement program of B. ruziziensis. This program aims to identify high-yield genotypes with improved forage quality and resistant to major biotic and abiotic stresses. In order to assist the B. ruziziensis improvement program, this study aimed to estimate the genetic variability among $B$. ruziziensis genotypes, and contribute with information about the genetic basis of Embrapa's collection through the use of ISSR markers. The results of this work will be used for monitoring the genetic variability of genotypes under evaluation and also to direct crosses between divergent genotypes to explore heterosis. The information obtained will be important for defining breeding strategies and methods to be adopted by the program in order to make it more dynamic, increasing the chances of successful selection.

\section{MATERIAL AND METHODS}

A total of 93 genotypes of Embrapa's collection of B. ruziziensis genetic improvement program were selected for this diversity study. Outgroup genotypes were used to provide a reference point against which genetic similarity of $B$. ruziziensis could be evaluated for generating the trees. The genotypes used as outgroup were: B. brizantha (cvs. Marandu and Xaraes), B. decumbens (cv. Basilisk), B. humidicola (cv. Llanero), Brachiaria spp (B. spp) and millet (Pennisetum glaucum).

Leaves were harvested and genomic DNA was extracted based on the protocol described by Ferreira and Grattapaglia (1995) with modifications. ISSR reactions contained: $0.5 \mathrm{mM}$ primer, $100 \mathrm{mM}$ Tris- $\mathrm{HCl}(\mathrm{pH} 8.4), 500 \mathrm{mM} \mathrm{KCl}, 1.5$ or $2.0 \mathrm{mM} \mathrm{MgCl}_{2}$ (depending on the primer), $0.15 \mathrm{mM}$ dNTP, $1 \mathrm{U}$ Taq DNA polymerase and $30 \mathrm{ng}$ genomic DNA in a final volume of $25 \mu \mathrm{L}$. The 12 primers used were developed at the University of British Columbia Laboratory of Biotechnology (UBC-808, UBC-809, UBC-815, UBC-820, UBC823, UBC-826, UBC-830, UBC-841, UBC-845, UBC-851, UBC-857, UBC-859). The amplifications were performed in a GeneAmp PCR System 9700 thermocycler (Applied Biosystems, Foster City, CA, USA) under the following conditions: initial denaturation at $94^{\circ} \mathrm{C}$ for $4 \mathrm{~min}$, followed by 45 cycles of one minute at $94^{\circ} \mathrm{C}, 45 \mathrm{~s}$ at $50^{\circ} \mathrm{C}$ and $2 \mathrm{~min}$ at $72^{\circ} \mathrm{C}$, and a final extension step of $7 \mathrm{~min}$ at $72^{\circ} \mathrm{C}$.

The DNA fragments were separated by electrophoresis on $2 \%$ agarose gels, for $5 \mathrm{~h}$ at $120 \mathrm{~V}$. Each gel was stained by immersion in $3 \mathrm{mg} / \mathrm{mL}$ ethidium bromide solution for $30 \mathrm{~min}$ and then photographed under ultraviolet light using the Eagle Eye II photo documentation system (Stratagene, La Jolla, CA, USA). The size of amplified fragments was estimated by comparison with a 200-bp molecular ladder (Promega, Madison, WI, USA).

The scoring of the markers was performed using the RFLPscan program (Scanalytics, Fairfax, VA, USA). Only fragments of good resolution and high intensity were considered in the analysis. The allelic data for all genotypes was scored in the form of a binary matrix, where 1 represented the presence and 0 the absence of a DNA band. The genetic distance for all the pairwise combinations was calculated using Jaccard's similarity coefficient (Jaccard, 1908). The genetic distance matrix was used to generate a dendrogram using the unweighted pair group method with arithmetic mean (UPGMA). The consistency of the dendrogram was eval- 
uated by the correlation between the dissimilarity matrix and cophenetic matrix (Sokal and Rohlf, 1962). The analysis of molecular variance (AMOVA) to check population structuring was carried out according to Excoffier et al. (1992), using the software GENES (Cruz, 2008).

\section{RESULTS AND DISCUSSION}

The 12 ISSR primers generated 89 polymorphic bands, which were used to estimate the genetic diversity among 93 genotypes of $B$. ruziziensis and the six outgroup genotypes. The number of bands identified in each primer ranged from two (primer UBC-826) to 13 (primer UBC-823) with an average of 7.41 bands per primer (Table 1). Monomorphic bands were not identified, which could be an indication of the high variability among the genotypes. The length of the bands ranged from $300-1560 \mathrm{bp}$. A total of 33 unique bands were identified in all genotypes: 15 bands were found in B. ruziziensis (genotypes 7, 8, 11, 27, 42, 57, 58, 97, 101 and 102) and 18 bands belonged to the outgroup. Similar results were obtained by Ambiel et al. (2010), who conducted a study with 10 RAPD markers and 42 samples, including different species of Brachiaria. They found 114 bands (all polymorphic) with an average of 11.4 bands/primer. Guaberto (2009) identified 184 polymorphic bands in a total of 202 (14 bands/ primer), using 14 RAPD markers in B. ruziziensis.

\begin{tabular}{|c|c|c|c|}
\hline Primer & Number of bands & Primer & Number of bands \\
\hline UBC-808 & 12 & UBC- 830 & 7 \\
\hline UBC-809 & 6 & UBC-841 & 11 \\
\hline UBC-815 & 9 & UBC-845 & 3 \\
\hline UBC-820 & 12 & UBC-851 & 7 \\
\hline UBC-823 & 13 & UBC-857 & 3 \\
\hline UBC-826 & 2 & UBC-859 & 4 \\
\hline
\end{tabular}

In general, ISSR markers detect high levels of polymorphism (Powell et al., 1996; Joshi and Dhawan, 2007; Sreedhar et al., 2007). ISSR fingerprinting detected more polymorphic bands (12.8\%) than RAPD fingerprinting (4.28\%) in micropropagated tea clones (Devarumath et al., 2002). Prevost and Wilkinson (1999) used only four ISSR primers to completely distinguish 34 potato cultivars. In our study, 89 bands (all polymorphic) generated by 12 ISSR primers were able to explore the genomic variation among 93 genotypes of $B$. ruziziensis.

Cluster analysis revealed by the dendrogram indicates genetic variability among the B. ruziziensis genotypes (Figure 1). There is a clear formation of a group containing most of the genotypes of B. ruziziensis distinct from the outgroup genotypes. Besides, three genotypes of B. ruziziensis were gathered with the outgroup (42, 74 and 68). The UPGMA cluster analysis clustered the 99 genotypes into three main groups (Figure 1). Group A included 92 genotypes of $B$. ruziziensis and four outgroup genotypes $[B$. decumbens, B. brizantha (cv. Marandu and Xaraes) and B. spp.]. Group B consisted of only one genotype of B. ruziziensis (genotype 42), and group $C$ included two outgroup genotypes (B. humidicola and Pennisetum glaucum). The dendrogram showed a cophenetic correlation matrix of 0.87 , indicating a high goodness-of-fit. Similar results were obtained by Ambiel et al. (2010), assessing the genetic divergence among accessions from different Brachiaria species by RAPD markers, where $B$. 
humidicola was separated from all the other Brachiaria species and where B. ruziziensis, $B$. decumbens and $B$. brizantha were clustered in the same group by the dendrogram generated from genetic dissimilarity estimates.

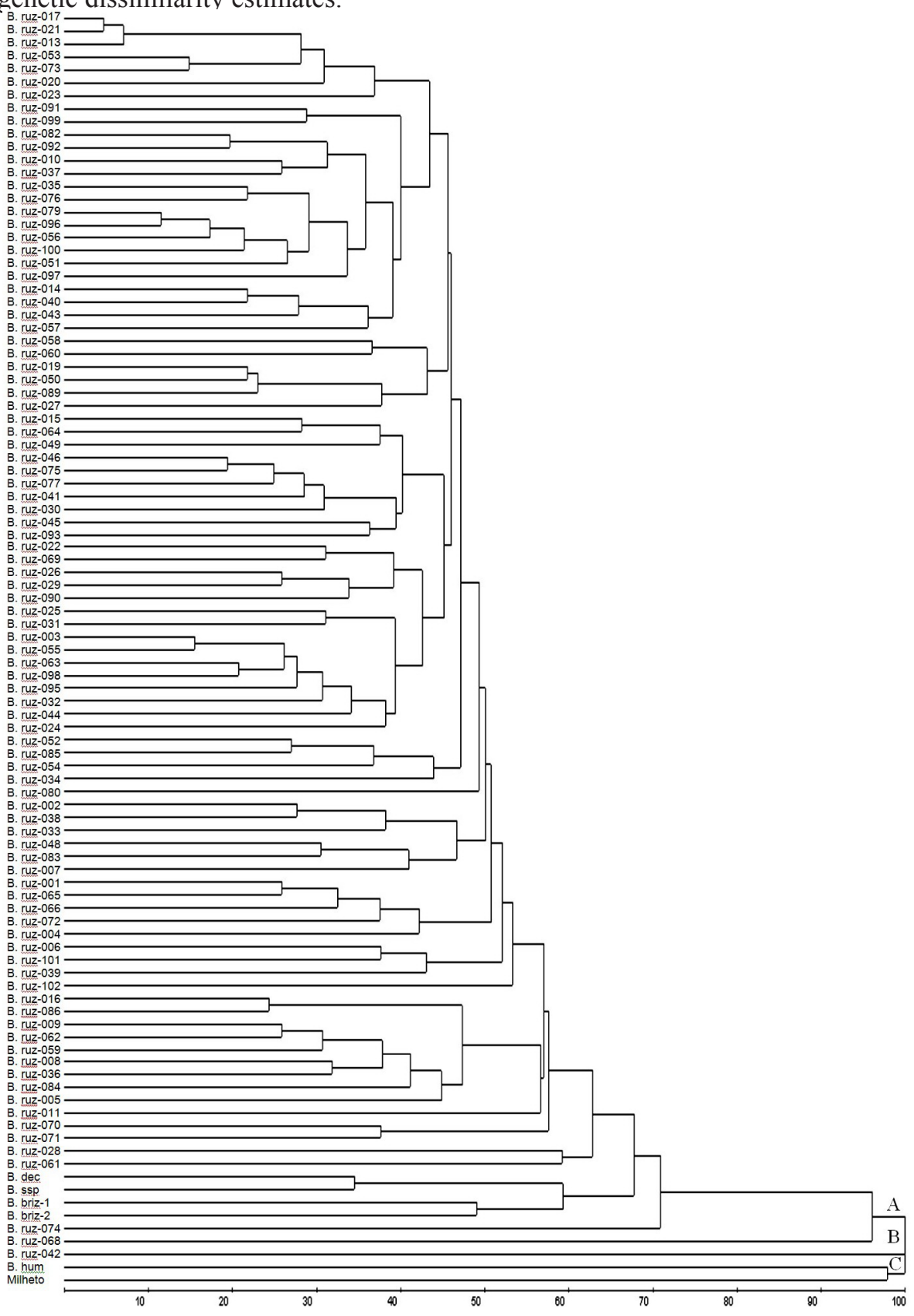

Figure 1. Dendrogram analysis of 93 Brachiaria ruziziensis and six outgroup genotypes revealed by ISSR markers, generated by Jaccard's similarity coefficient. 
A similarity matrix for the 99 genotypes was constructed. The frequency distribution of the coefficients indicated an average coefficient between genotypes of 0.47 (Figure 2). Between $B$. ruziziensis genotypes only, the genetic similarity coefficients ranged from 0 to 0.95 , with an average of 0.50 , attesting to the genetic variability within the species. We also found that $84 \%$ of the estimated coefficients showed values below 0.6 , and 99 pairs did not share any bands, reflecting the high level of genetic variability among the genotypes used in this study. Souza Sobrinho et al. (2009 and 2010) also reported the existence of high genetic variability in $B$. ruziziensis for traits related to yield and quality of forage produced as well as for tolerance to biotic and abiotic stresses. Chiari et al. (2008) used RAPD markers to access the genetic variability of four species of Brachiaria and concluded that the greatest dissimilarities were observed among $B$. ruziziensis genotypes ( 0.73 to 0.83 ).

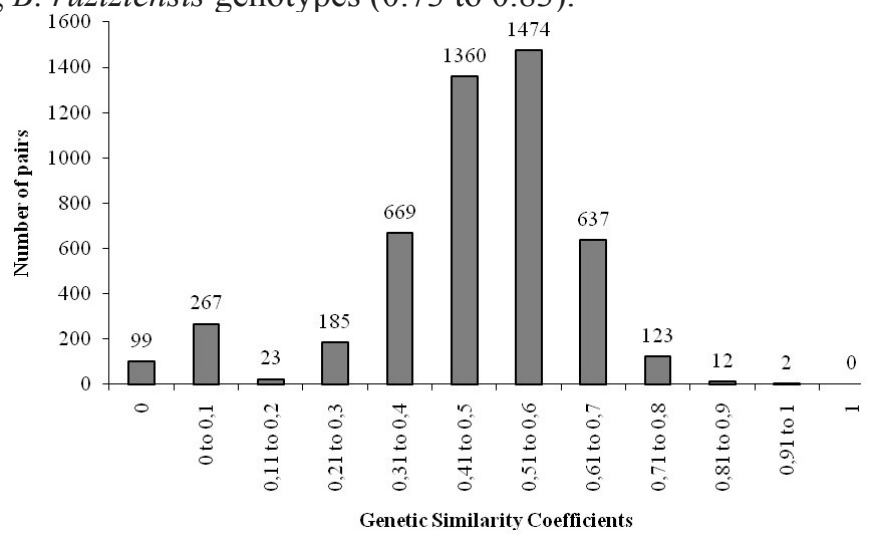

Figure 2. Frequency distribution of genetic similarity coefficients between 93 Brachiaria ruziziensis and six outgroup genotypes.

Among the genotypes, a total of 89 polymorphic bands were identified. Thirty three were found to be unique bands from 10 genotypes of $B$. ruziziensis $(7,8,11,27,42,57,58$, 97, 101 and 102), and the other bands were identified in the outgroup. Genotype 42 showed six unique bands, which highlights its highest divergence when compared to all other genotypes. These unique bands could be used to quickly and reliably identify this genotype, which could be extremely useful in the breeding program. Confirmation of hybridization after execution of controlled crossings, for instance, is a practical example of the usefulness of these markers. Within the genus Brachiaria, such crossings are usually carried out without emasculating the flowers and the identification of hybrid individuals is highly demanded by the breeding programs.Genetic relationship based on molecular markers is helpful in selecting parental combinations for hybrid crop breeding so as to gain desirable traits (Becelaere et al., 2005; Ali et al., 2008). These results could be used as auxiliary tools to help Brachiaria breeders to select appropriate parents in their breeding programs to maximize yield as well as to maintain genetic diversity. The use of genotypes of high genetic diversity is a strategy used by breeders to maximize heterosis or hybrid vigor. Thus, the recommendation of crossings should prioritize the use of genotype or group of genotypes with high genetic distances.

The UPGMA dendrogram shows high genetic variability among B. ruziziensis geno- 
types (Figure 1). These conclusions were further strengthened by AMOVA, which indicated more variation within $(73.43 \%)$ than between populations (26.57\%) (Table 2). Cross-pollinating species are, by definition, much more variable than self-pollinating species (Yanaka et al., 2005). B. ruziziensis is a cross-pollinating species (Souza Sobrinho et al., 2009), so it is expected that greater variability was found within the species. Guaberto (2009) and Ambiel et al. (2010) worked with RAPD markers in different species of Brachiaria and found similar results, which confirms the predominance of genetic variability within species. Higher variation within groups was also observed in cross-pollinating species such as Buffalo grass (Huff et al., 1993), Lolium multiflorum (Vieira et al., 2004), Bromus innermis (Diaby and Casler, 2005); Bromus riparius Rehm (Ferdinandez et al., 2001), B. auleticus (Rivas, 2001), Chloris gayana K. (Ubi et al., 2003), Pascopryum smithii (Larson et al., 2003) and Eucalyptus globulus (Nesbitt et al., 1995). In Napier grass, RAPD analysis found 35\% variation between and $65 \%$ within groups based on geographical origin (Lowe et al., 2003). Thus, the present material indicates wide range of diversity available for breeding. This large variability reduces the chance of genetic drift and inbreeding, thus contributing to the maintenance of high genetic diversity within populations.

Table 2. Analysis of molecular variance between and within Brachiaria populations.

\begin{tabular}{lcccc}
\hline Source of variation & d.f. & Sum of squares & Mean squares & \% variation \\
\hline Between populations & 1 & 28.281 & 28.28 & 26.57 \\
Within populations & 97 & 540.10 & 5.56 & 73.43 \\
Total & & & &
\end{tabular}

\#Population 1: Brachiaria ruziziensis; Population 2: outgroup genotypes.

According to Hamrick (1983), the distribution of genetic variation is not random within populations; it is determined by the reproductive system, geographic distribution, effective size of populations, mode of reproduction and gene flow through dispersal of pollen. Besides these features, evolutionary factors acting on the genetic diversity, introducing new alleles or modifying the frequencies (Weir, 1990). The existence of genetic variability within $B$. ruziziensis, revealed by molecular markers, increases the chance of success of the B. ruziziensis breeding program, since this is the only species of Brachiaria grown in Brazil that is diploid and sexual, allowing recombination and selection of superior genotypes (Souza Sobrinho et al., 2009). Furthermore, the molecular characterization of genotypes is also important for monitoring the genetic variability along the selection cycles. Thus, the estimates of genetic divergence, based on molecular markers, will help to determine if the rate of selection is appropriate, as well as to maintain sufficient variability to select the breeding cycles.

\section{CONCLUSION}

ISSR markers were effective in assessing the genetic variability within genotypes of Brachiaria ruziziensis, given the large number of markers identified and the high polymorphism found, and the data suggest that this population has a wide genetic base suitable for breeding.

\section{ACKNOWLEDGMENTS}

Research supported by CNPq, FAPEMIG and UNIPASTO. 


\section{REFERENCES}

Ali ML, Rajewski JF, Baenziger PS, Gill KS, et al. (2008). Assessment of genetic diversity and relationship among a collection of US sweet sorghum germplasm by SSR markers. Mol. Breed. 21: 497-509.

Ambiel AC, Machado Neto NB, Guaberto LM and Vanderlei TM (2010). Brachiaria germplasm dissimilarity as shown by RAPD markers. Crop Breed. Appl. Biotechnol. 10: 55-64.

Balasaravanan T, Pius PK, Kumar RR, Muraleedharan N, et al. (2003). Genetic diversity among south Indian tea germplasm (Camellia sinensis, C. assamica and C. assamica spp. lasiocalyx) using AFLP markers. Plant Sci. 165: 365-372.

Becelaere GV, Edward LL, Paterson AH and Chee PW (2005). Pedigree- vs. DNA marker-based genetic similarity estimates in cotton. Crop Sci. 45: 2281-2287.

Bonato ALV, Calvo ES, Geraldi IO and Arias CAA (2006). Genetic similarity among soybean (Glycine max (L) Merrill) cultivars released in Brazil using AFLP markers. Genet. Mol. Biol. 29: 692-704.

Chiari L, Rocha M, Valle CB and Salgado LR (2008). Variabilidade Genética em Acessos e Cultivares de Quatro Espécies de Brachiaria Estimada por Marcadores RAPD. Boletim de Pesquisa e Desenvolvimento, Embrapa Gado de Corte, Campo Grande.

Cruz CD (2008). Programa Genes - Diversidade Genética. $1^{a}$ ed. Editora UFV, Viçosa.

Dávila JA, Loarce Y and Ferrer E (1999). Molecular characterization and genetic mapping of random amplified microsatellite polymorphism in barley. Theor. Appl. Genet. 98: 265-273.

Devarumath R, Nandy S, Rani V, Marimuthu S, et al. (2002). RAPD, ISSR and RFLP fingerprints as useful markers to evaluate genetic integrity of micropropagated plants of three diploid and triploid elite tea clones representing Camellia sinensis (China type) and C. assamica ssp assamica (Assam-India type). Plant Cell Rep. 21: 166-173.

Diaby M and Casler MD (2005). RAPD marker variation among divergent selections for fiber concentration in smooth bromegrass. Crop Sci. 45: 27-35.

Dusi DMA (2001). Apomixis in Brachiaria decumbens Stapf. PhD. thesis, Wageningen University, Wageningen.

Excoffier L, Smouse PE and Quattro JM (1992). Analysis of molecular variance inferred from metric distances among DNA haplotypes: application to human mitochondrial DNA restriction data. Genetics 131: 479-491.

Ferdinandez YSN, Somers DJ and Coulman BE (2001). Estimating the genetic relationship of hybrid bromegrass to smooth bromegrass and meadow bromegrass using RAPD markers. Plant Breed. 120: 149-153.

Ferreira ME and Grattapaglia D (1995). Introdução ao Uso de Marcadores Moleculares em Análise Genética. Embrapa, Brasília.

Guaberto LM (2009). Identificação da Variabilidade Genética de Brachiaria ruziziensis por Marcadores Moleculares. Master's thesis, Universidade do Oeste Paulista, Presidente Prudente.

Hamrick JL (1983). The Distribution of Genetic Variation Within and Among Natural Forest Population. In: Genetics and Conservation (Schonewaldcox CM, ed.). Benjamin/Cummings, Menlo Park, 335-348.

Huff DR, Peakall R and Smouse PE (1993). RAPD variation within and among natural population of out crossing buffalo grass (Buchloe dactyloides (Nutt.) Englm.). Theor. Appl. Genet. 86: 927-934.

Jaccard P (1908). Nouvelles recherches sur la distribution florale. Bul. Soc. Vaudoise Sci. Nat. 44: 223-270.

Joshi P and Dhawan V (2007). Assessment of genetic fidelity of micropropagated Swertia chirayita plantlets by ISSR marker assay. Biol. Plant 51: 22-26.

Kapila RK, Yadav RS, Plaha P, Rai KN, et al. (2008). Genetic diversity among pearl millet maintainers using microsatellite markers. Plant Breed. 127: 33-37.

Khan IA, Awan FS, Ahmad A, Fu YB, et al. (2005). Genetic diversity of Pakistan wheat germplasm as revealed by RAPD markers. Genet. Res. Crop Evol. 52: 239-244.

Larson SR, Palazzo AJ and Jensen KB (2003). Identification of western wheatgrass cultivars and accessions by DNA fingerprinting and geographic provenance. Crop Sci. 43: 394-401.

Lowe AJ, Thorpe W, Teale A and Hanson J (2003). Characterisation of germplasm accessions of Napier grass (Pennisetum purpureum and $P$. purpureum $\times$ P. glaucum hybrids) and comparison with farm clones using RAPD. Genet. Res. Crop Evol. 50: 121-132.

Macedo MCM (2009). Integração lavoura e pecuária: o estado da arte e inovações tecnológicas. Rev. Bras. Zootec. 38: 133-146.

Martha Júnior GB and Corsi M (2001). Pastagens no Brasil: situação atual e perspectivas. Preços Agrícolas 15: 3-6.

Martos V, Royo C, Rharrabti Y and Garcia del Moral LF (2005). Using AFLPs to determine phylogenetic relationships and genetic erosion in durum wheat cultivars released in Italy and Spain throughout the 20th century. Field Crop Res. 91: 107-116. 
Nesbitt KA, Potts BM, Vaillancourt RE, West AK, et al. (1995). Partitioning and distribution of RAPD variation in forest tree species, Eucalyptus globulus (Myrtaceae). Heredity 74: 628-637.

Pereira AV (1998). Melhoramento Genético de Plantas Forrageiras. In: Simpósio Sobre Atualização em Genética e Melhoramento de Plantas. UFLA/FAEPE, Lavras, 135-162.

Powell W, Morgante M and Andre C (1996). The comparison of RFLP, RAPD, AFLP and SSR (microsatellite) markers for germplasm analysis. Mol. Breed. 2: 225-238.

Prevost A and Wilkinson MJ (1999). A new system of comparing PCR primers applied to ISSR fingerprinting of potato accessions. Theor. Appl. Genet. 98: 107-112.

Reddy MP, Sarla N and Siddiq EA (2002). Inter simple sequence repeat (ISSR) polymorphism and its application in plant breeding. Euphytica 128: 9-17.

Rivas M (2001). Sistema reproductivo y estructura genética de poblaciones de Bromus auleticus Trinius ex-Nees (Poaceae). Estudio mediante isoenzimas. Agrociencia 5: 32-40.

Russell JR, Fuller JD, Macaulay M, Hatz BG, et al. (1997). Direct comparison of levels of genetic variation among barley accessions detected by RFLPs, AFLPs, SSRs and RAPDs. Theor. Appl. Genet. 95: 714-722.

Sokal RR and Rohlf FJ (1962). The comparison of dendrograms by objective methods. Taxon 9: 33-40.

Souza Sobrinho F, Lédo FJS, Kopp MM, Pereira AV, et al. (2009). Melhoramento de Gramíneas Forrageiras na Embrapa Gado de Leite. In: Forragicultura e Pastagem (Evangelista AR and Souza FF, eds.). Editora UFLA, Lavras, 98-111.

Souza Sobrinho F, Auad AM and Lédo FJS (2010). Genetic variability in Brachiaria ruziziensis for resistance to spittlebugs. Crop Breed. Appl. Biotechnol. 10: 83-88.

Sreedhar RV, Venkatachalam L and Bhagyalakshmi N (2007). Genetic fidelity of long-term micropropagated shoot cultures of vanilla (Vanilla planifolia Andrews) as assessed by molecular markers. Biotechnol. J. 2: 1007-1013.

Terzopoulos PJ, Kolano B, Bebeli PJ, Kaltsikes PJ, et al. (2005). Identification of Olea europaea L. cultivars using intersimple sequence repeat markers. Sci. Hortic. 105: 45-51.

Ubi BE, Kölliker R, Fujimori M and Komatsu T (2003). Genetic diversity in diploid cultivars of rhodes grass determined on basis of amplified fragment length polymorphism markers. Crop Sci. 43: 1516-1522.

Vieira EA, Castro CM, Oliveira AC, Carvalho FIF, et al. (2004). Genetic structure of annual ryegrass (Lolium multiflorum) populations estimated by RAPD. Sci. Agric. 61: 407-413.

Weir BS (1990). Genetic Data Analysis: Methods for Discrete Population Genetic Data. Sinauer Associates, Sunderland.

Yanaka YF, Dall'Agnol M, Schifino-Wittmann MT, Dias PMB, et al. (2005). Variabilidade genética em populações naturais de Bromus auleticus Trin. ex Nees (Poaceae) com base em isoenzimas e marcadores RAPD. Rev. Soc. Bras. Zootec. 34: 1897-1904. 